DOI: $10.19195 / 2300-7729.37 .9$

\author{
TERESA SKIBICKA
}

ORCID: 0000-0002-0123-7144

Biblioteka Główna Uniwersytetu Technologiczno-Przyrodniczego w Bydgoszczy

\title{
Jeszcze o wizerunku biblioteki i bibliotekarza z perspektywy popularnych mediów
}

\section{Wstęp}

Od czasu do czasu w środowisku bibliotekarskim odżywa dyskusja na temat społecznego odbioru biblioteki jako instytucji, sposobu postrzegania jej pracowników oraz zawodu bibliotekarza. W latach dziewięćdziesiątych ubiegłego wieku pojawiły się artykuły omawiające wyniki badań ankietowych, mających na celu uzyskanie odpowiedzi na pytanie, jak użytkownicy oceniają bibliotekę i zatrudniony w niej personel ${ }^{1}$. Ponadto wielu bibliotekarzy, w kuluarach spotkań branżowych, dzieliło się osobistymi refleksjami na ten temat. Jednak najszerzej zakrojona dyskusja przetoczyła się przez środowisko w pierwszej dekadzie dwudziestego pierwszego wieku. Spowodowały ją artykuły Jak wyglada bibliotekar$k a$ ? (części pierwsza i druga) ${ }^{2}$. Ponieważ nie przedstawiały one pochlebnego wizerunku pracownika biblioteki, wywołały mnóstwo polemik i refleksji. Niektórzy bibliotekarze odebrali ten obraz bardzo emocjonalnie. Inni starali się tonować wzburzenie, przekonani, że badania ujawniają nie prawdziwy wizerunek, lecz funkcjonujący od dawna stereotyp bibliotekarza, ,tak powszechny, że aż banalny"3. Zastanawiano się nie tylko nad przyczynami jego powstania, lecz także żywotnością, trwającą niezależnie od zmieniającego się świata. Podjęto debatę nad znalezieniem metod walki z krzywdzącymi, nieprawdziwymi uogólnieniami, dyskutowano o sposobach dokonania zmian na lepsze w funkcjonowaniu bibliotek, o poprawieniu odbioru społecznego bibliotekarzy. Rodzą się zatem pytania:

1 J. Przybylska, Bibliotekarze w opinii czytelników, „Bibliotekarz” 1995, nr 11, s. 18-22.

2 A. Firlej-Buzon, Jak wyglada bibliotekarka?, „Poradnik Bibliotekarza” 2003, nr 9, s. 3-6; eadem, Jak wyglada bibliotekarka? Cz. 2, „Poradnik Bibliotekarza” 2004, nr 1, s. 8-10.

3 P. Marcinkowski, Bibliotekarz. Stereotyp czy wizerunek?, http://eprints.rclis.org/7083/1/ stereotyp.pdf [dostęp: 19.09.2017]. 
Jaki jest obecnie efekt tych wysiłków? Czy zostały zauważone przez społeczeństwo? Czy znalazły odzwierciedlenie w mediach? Jeśli tak, to w jaki sposób dzisiaj przedstawia się biblioteki i pracujące w nich osoby?

\section{Materiał badawczy}

Jednym ze sposobów na poznanie opinii krążących w społeczeństwie, a zatem także poglądów, jakie na temat bibliotek i bibliotekarzy mają osoby niezwiązane zawodowo z tym obszarem, jest przegląd mediów. Materiały, na jakie się powołano w niniejszym artykule, pochodzą z lat 2011-2018. W tym celu przejrzano zawartość wybranych dzienników, tygodników i miesięczników oraz ich stron internetowych. Dzienniki reprezentują trzy tytuły prasy lokalnej z regionu kujawsko-pomorskiego: „Express Bydgoski”, „Gazeta Pomorska” i „Nowości. Dziennik Toruński” oraz dwa tabloidy o zasięgu ogólnopolskim: „Fakt” i „Super Express”. Przeanalizowano pięć tygodników opiniotwórczych: „Do Rzeczy”, „Newsweek”, „Polityka”, „Wprost”, „wSieci” i prasę kobiecą: „Na Żywo”, „Rewia”, „Twoje Imperium”, „Świat i Ludzie”, „Życie na Gorąco” (tygodniki) oraz „Dobre Rady”, „Kobieta i Życie”, „Poradnik Domowy” (miesięczniki). Dodatkowo zostały przytoczone cytaty z kilku książek beletrystycznych, w których przypadkowo natrafiono na fragmenty dotyczące sfery bibliotecznej.

\section{Wizerunek biblioteki}

Zauważono, że opinie o bibliotekach pojawiają się dość rzadko w obiegu społecznym, a jeśli już są obecne — instytucje te są zazwyczaj postrzegane pozytywnie ${ }^{4}$. Prawdopodobnie wiąże się to $\mathrm{z}$ tym, że biblioteka, w zależności od celu składania w niej wizyty, może być kojarzona z nauką i edukacją lub z rozrywką - miłym, ciekawym sposobem spędzania czasu. We wrześniu 2006 roku uczestnicy Ogólnopolskiego Seminarium „Kształtowanie wizerunku biblioteki”5 podjęli próbę diagnozy problemu oraz odpowiedzi na pytanie: Co i jak można zmienić w rysującym się wizerunku?

Okazało się, iż biblioteka to instytucja skostniała na tyle, że stanowi „,cichą przystań"6 dającą poczucie bezpiecznej niezmienności tym pracownikom, którzy cenią stałość. Z punktu widzenia użytkowników biblioteka to instytucja konser-

4 „Mianowicie istnieją potoczne, obiegowe stereotypy biblioteki oraz obiegowe, potoczne stereotypy postaci bibliotekarza [...]. Prawdę mówiąc, stereotyp biblioteki jest korzystniejszy" J. Wojciechowski, W imadle stereotypów, „Bibliotekarz” 2004, nr 2, s. 3.

5 Kształtowanie wizerunku biblioteki, red. M. Czyżewska, Białystok 2007.

6 B. Szczepańska, Cicha przystań?, „EBIB” 1999, nr 1, http//www.oss.wroc.pl/biuletyn/ ebib01/cicha_przystan.html [dostęp: 26.09.2017]. 
watywna, niechętnie poddająca się zmianom, której jedyna funkcja polega na wypożyczaniu książek. Co gorsza, ,jest duża grupa ludzi, która nie widzi nawet tej funkcji biblioteki"'. Bywa też instytucją opresyjną — na przykład Bogumił Kobiela nie mógł odebrać dyplomu ukończenia studiów aktorskich, gdyż nie oddał książek do biblioteki ${ }^{8}$.

Na podstawie analizy treści źródeł stanowiących materiał badawczy do niniejszego artykułu można stwierdzić, że po latach sposób postrzegania biblioteki nie uległ większej zmianie. Tak jest zarówno w znalezionych tekstach krajowych, jak i obcych. Przykładowo, B. Bryson, podróżując po Wielkiej Brytanii, pisze: „Nawet w klubach robotniczych, których Ashington w szczytowym okresie miało dwadzieścia dwa, były biblioteki i czytelnie dla tych, których potrzeby nie ograniczały się do dwóch dużych jasnych”. I dalej: „Thurso przeżyło swój wielki dzień w 1834 roku, kiedy sir John Sinclair pracowicie rozbudowywał miasto, dając mu w prezencie wspaniałą bibliotekę"10. Po czym autor wyraża żal, że te wspaniałe czasy już przeminęły: „A potem znikały jedno po drugim - towarzystwo teatralne, towarzystwo operowe, czytelnie i sale wykładowe"11. W podobnym tonie utrzymany jest artykuł Jak znika Polska powiatowa opublikowany na łamach gazety „Nowości. Dziennik Toruński”: „W latach 2000-2010 w kujawsko-pomorskim ubyło 176 szkół podstawowych, 38 bibliotek publicznych i 322 kilometry linii kolejowych. Każda z tych liczb oznacza wyrwę w życiu lokalnej społeczności i niejeden ludzki dramat" ${ }^{\prime 2}$. W oczach publicysty biblioteki są niezastąpione i bardzo potrzebne - na równi ze szkołami i komunikacją publiczną. „Biblioteka jest nudna? Nigdy w życiu!” — oświadcza „Poradnik Domowy” w artykule Ich praca uśmiech przywraca ${ }^{13}$. Ze zdjęć spoglądają atrakcyjne kobiety — bibliotekarki z Morąga. To one pomyślały o stworzeniu kalendarza ilustrowanego zdjęciami biblioteki i jej pracownic. Chciały w ten sposób przyczynić się do zmiany sposobu postrzegania swojej placówki, odbieranej dotąd w mieście jako miejsce nieatrakcyjne czy wręcz staroświeckie. A przecież, jak donoszą „Dobre Rady”:

Biblioteka tętni życiem. [...] Wnętrza biblioteki [...] są jasne i nowoczesne. Mieszkańcy chętnie tu zaglądają. [...] Kiedy zaczęła tu pracować, mało kto przychodził do biblioteki w celu innym niż wypożyczenie książki. Teraz jest ona centrum spotkań w naszej gminie ${ }^{14}$.

7 D. Sawicka, Obalić mity, ,EBIB” 2004, nr 5, http://www.ebib.pl/2004/56/sawicka.php [dostęp: 27.10.2017].

8 Bogumit Kobiela. Przeczuwat, że szybko odejdzie, „Na Żywo” 2017, nr 10, s. 42.

9 B. Bryson, Zapiski z małej wyspy, przeł. T. Bieroń, Poznań 2009, s. 237.

10 Ibidem, s. 261.

11 Ibidem, s. 237.

12 J. Jakubowski, Jak znika Polska powiatowa, „Nowości. Dziennik Toruński” 2012, nr 108, http://www.nowosci.com.pl/archiwum/a/jak-znika-polska-powiatowa,10923891/ [dostęp: 26.04.2012].

13 E. Golisz, Ich praca uśmiech przywraca, „Poradnik Domowy” 2014, nr 10, s. 36-38.

14 M. Oszmian, K. Leszczyńska, Jak dobrze wrócić w rodzinne strony!, „Dobre Rady” 2015, nr 9, s. 44-47. 
I nie tylko. Są też takie placówki, przed którymi rysuje się jeszcze ciekawsza przyszłość — Biblioteka na miarę XXI wieku:

Zmiany będą rewolucyjne. W efekcie uzyskania grantu rysuje się szansa, że WiMBP w Bydgoszczy zaoferuje swoim użytkownikom między innymi poświęcony literaturze escaperoom, książkomaty, wrzutomaty, różne aplikacje na urządzenia mobilne. Oferta biblioteczna poszerzy się o elementy gamingu i gier miejskich opartych o rzeczywistość rozszerzoną $\mathrm{ARG}^{15}$.

Jeśli zatem projekt się powiedzie, ma szansę stracić na aktualności znaleziony w Internecie dowcip: „Na zapleczu miejskiej biblioteki policja odkryła hodowlę marihuany. Okoliczni mieszkańcy w szoku — nie mieli pojęcia, że jest tu biblioteka"16. Czy jednak można się dziwić, że sporo osób unika bywania w bibliotece, skoro wyjątkowo niepochlebnie wypowiedziała się o niej znana tancerka I. Pavlović? Wyznała ona: „dostałam się na bibliotekoznawstwo. Niestety, nie przepracowałam w tym zawodzie ani godziny, a na praktykach w bibliotece od razu zasypiałam. Do dziś to miejsce działa na mnie usypiająco"17. Być może celebrytka zmieniłaby zdanie, gdyby miała okazję odbywać praktyki w bibliotece w bydgoskiej dzielnicy Okole. Tam „książki weszły w XXI wiek. [...] Liczba czytelników wzrosła o około pięćset osób. Odwiedzają nas całe rodziny. [...] Z ulicy widać czytających ludzi, korzystających z komputerów, widać regały. To przyciąga. Atuty tego miejsca można by wymieniać długo"18. Zapewne z podobnej placówki korzysta autor artykułu Pean na cześć bibliotek. Jak pisze felietonista,

biblioteki to chyba najlepiej działające instytucje publiczne w Polsce. Instytucje z przydomkiem „publiczna” są zazwyczaj dziadowskie [...], skomplikowane, zamknięte po godz. 16, niezachęcające i robią zawsze tak, żeby było trudniej [...]. Natomiast biblioteki publiczne to zupełnie inna, pozytywna rzeczywistość. Owszem, zazwyczaj bywają małe i niedofinansowane, ale zdarzają się też takie jak absolutne cudo w Sochaczewie. Niezależnie od tego, czy są ascetyczne czy bizantyjskie i z kącikami zabaw dla dzieci, wszędzie (a przynajmniej tam, gdzie bywałem), są prawdziwymi sercami lokalnych społeczności. Animują, organizują, przyciągają, interesują. [...] W polskiej bibliotece panuje wspaniała, kulturalna atmosfera. [...] Ważne, że ludzie masowo walą do tych bibliotek. Młodzi też. To cudowne, że taki świat istnieje. Tego nie da się przecenić ${ }^{19}$.

Pewnych śladów stereotypów mówiących o tym, że w bibliotekach bywa biednie i nudno, można się dopatrzyć w artykułach z dzienników lokalnych. Gdy „Gazeta Pomorska” zamieszcza artykuł pt. „Sztuka przetrwania” w bibliotece

15 Biblioteka na miarę XXI wieku, „Express Bydgoski” 2017, nr 197, s. 23.

$16 \mathrm{http} / /$ demotywatory.pl/4493808/Na-zapleczu-miejskiej-biblioteki-policja-odkrylahodowle-marihuany [dostęp: 3.10.2017].

17 I. Pavlović, Mąż zdobyt mnie podstepem, „Super Express” 2011, http://www.se.pl/wiadomosci/gwiazdy/iwona-pavlovic-maz-zdoby-mnie-podstepem_207112.html [dostęp: 4.10.2017]; eadem, Dla taty byłam księżniczka, „Na Żywo” 2011, nr 39, s. 19.

${ }^{18}$ K. Bogucka, To książkowa metamorfoza!, „Express Bydgoski”2016, http://www.expressbydgoski.pl/kultura/a/to-ksiazkowa-metamorfoza-biblioteka-na-okolu,10821234/ [dostęp: 7.11.2017].

19 I. Zalewski, Pean na cześć bibliotek, „Do Rzeczy” 2014, nr 1, s. 63. 
miejskiej w Grudziądzu ${ }^{20}$, skojarzenia są różne - może to relacja o złej kondycji finansowej placówki, o kłopotach bibliotekarzy z czytelnikami lub odwrotnie? Tymczasem chodzi o inicjatywę pracowników grudziądzkiej książnicy polegającą na przygotowaniu spotkania ze znanym podróżnikiem, który dla chętnych poprowadził warsztaty surwiwalowe. Podobną sztuczką posłużył się „Express Bydgoski”, który zagrał na emocjach czytelników, nadając jednej z relacji chwytliwy tytuł: Bójka podczas debaty w bibliotece $U K W^{21}$. Czytelnik może zadać sobie pytanie: jak może być nudno w instytucji, w której emocje sięgają zenitu?

\section{Wizerunek bibliotekarza}

W ogólnym zarysie stereotypy na temat pracownika biblioteki można podzielić na odnoszące się do jego cech zewnętrznych oraz na te, które dotyczą zachowania wobec czytelnika i stosunku do wykonywanej pracy. Respondenci, proszeni o krótką charakterystykę bibliotekarek i/lub bibliotekarzy, zwracali uwagę głównie na ich wygląd. Uzyskany obraz trudno byłoby uznać za pochlebny. Najczęściej pojawiała się w nim szarość: „szara myszka”"22, „szara mysz i zasuszony kustosz” ${ }^{23}$. W potocznym rozumieniu bibliotekarka to „kobieta w średnim wieku, ubrana i uczesana niemodnie, osoba bezbarwna, smutna, nosząca okulary z grubymi szkłami" ${ }^{24}$. Z kolei skojarzenia z najczęstszym rodzajem zachowań bibliotekarzy można ująć w trzech kategoriach ${ }^{25}$. Są to: najrzadziej pojawiający się, akceptowalny stereotyp w rodzaju „skuteczny doradca, ale pyszałek, mądrala”; następnie dość rzadki stereotyp korzystny, czyli „zręczny profesjonalista”, „przyjazny rozmówca"; wreszcie stereotyp najgorszy, chociaż najbardziej powszechny: „cerber nie swoich zasobów”, ,antypatyczny zrzęda”, „fajtłapa, nieudacznik”, „sfrustrowany odludek, ekscentryk”. Wobec tych mocnych określeń warto zadać sobie pytanie: czy to jeszcze stereotyp, czy już wizerunek? ${ }^{26} \mathrm{~W}$ odpowiedzi na nie powstało zresztą sporo prac, do których można dotrzeć w oparciu o zestawienia bibliograficzne dostępne w Internecie ${ }^{27}$. Czy coś się zmieniło w tej kwestii?

20 „Sztuka przetrwania” w bibliotece miejskiej w Grudziądzu, „Gazeta Pomorska” 2017, nr 160, http://www.pomorska.pl/wiadomosci/grudziadz/a/sztuka-przetrwania-w-bibliotece-miejskiej-wgrudziadzu,12263573/ [dostęp: 12.07.2017].

21 Bójka podczas debaty w bibliotece UKW, „Express Bydgoski” 2017, nr 207, s. 2.

22 D. Sawicka, op. cit.

23 M. Zygmunt, Wizerunek bibliotekarki - czy się zmienia?, [w:] Ksztaltowanie wizerunku biblioteki..., s. 19.

24 A. Firlej-Buzon, Jak wyglada bibliotekarka?..., s. 3-6.

25 J. Wojciechowski, op. cit., s. 4.

26 P. Marcinkowski, op. cit.; B. Kowalska, D. Kotlarek, Bibliotekarz a stereotypy, „EBIB” 2006, nr 10, http://www.ebib.pl/2006/80/a.php?kowalska_kotlarek [dostęp: 19.09.2017].

27 D. Roszkowska, Wizerunek bibliotekarza. Zestawienie bibliograficzne w wyborze, http:// www.pedagogiczna.edu.pl/zest409.htm [dostęp: 30.06.2017]. 
W pierwszym odruchu można by powiedzieć, że niewiele. Choćby dlatego, że na przykład lektura przypadkowo wybranej, poczytnej książki z gatunku literatury sensacyjnej, przynosi takie oto opisy: „Krótko obcięte brązowe włosy, zero makijażu, a do tego okulary w metalowych oprawkach - wyglądała jak bibliotekarka”28. I w kolejnej: „Rooth westchnął. Od dwóch dni próbuje wycisnąć co się da z różnego rodzaju maniaków, [...] aż w końcu trafił do sauny z byłym bibliotekarzem"29. Te opisy wywołują wrażenie, że pisarz nie miał najlepszego zdania ani o aparycji, ani o walorach intelektualnych szwedzkich bibliotekarzy. Jednakże obie powieści zostały napisane w połowie lat dziewięćdziesiątych ubiegłego wieku — być może obecnie autor nie zamieściłby tak surowych opinii.

A jak to wygląda w krajowych źródłach? W Polsce tragiczne piętno na wizerunku zawodu odcisnęła zbrodnia popełniona na początku 2016 roku przez „niepozornego bibliotekarza z Warszawy, który samurajskim mieczem zabił młodą kobietę" 30 . Czyn ten wstrząsnął opinią publiczną nie tylko w Polsce, ale i na świecie. Opisując kulisy tej zbrodni, media starały się w każdym materiale zawrzeć wzmiankę o zawodzie wykonywanym przez oskarżonego (absolwenta filologii klasycznej i dziennikarstwa ${ }^{31}$ ), mimo braku znaczenia tego faktu dla sprawy. Jak bibliotekarz stat się morderca — zastanawiano się w „Newsweeku”32, a „Fakt” donosił:

Bibliotekarz morderca obciął kobiecie głowę piłą. Ustalenia prokuratorów o bibliotekarzu Kajetanie P.: Pozornie miły, uprzejmy i absolutnie niegroźny [...]. Oczytany, wykształcony bibliotekarz, z pozoru delikatny i niezdolny do przemocy. Kajetan P. pracował w bibliotece na Woli, a także szefował kołu naukowemu na jednym z uniwersytetów. [...] Znał ofiarę z biblioteki. Nauczycielka języka włoskiego, Katarzyna J. często bywała w bibliotece, w której pracował Kajetan P. ${ }^{33}$

Niestety, nie jest to jedyny pracownik biblioteki, który dopuścił się ciężkiego przestępstwa. Obecnie mało kto już pamięta, że L.H. Oswald, oskarżony o zabójstwo prezydenta J.F. Kennedy'ego, był pracownikiem Stanowej Biblioteki Podręczników Szkolnych w Dallas i z jej okna oddał strzały do prezydenta ${ }^{34}$.

W 2017 roku „Fakt” intrygował swoich czytelników chwytliwym tytułem: Obrzydliwy proceder Beaty P. Robiła to w bibliotece. Okazuje się, że „ładna, miła,

28 H. Nesser, Kobieta ze znamieniem, przeł. M. Kłos, Warszawa 2013, s. 20-21.

29 H. Nesser, Nieszczelna sieć, przeł. W. Łygaś, Warszawa 2012, s. 199.

30 M. Narbutt, Mroczne pasje bibliotekarza, ,wSieci” 2016, nr 7, s. 41.

31 Rodzina Kajetana Poznańskiego. Rodzice sa dobrze wyksztatceni i majętni, „Super Express” 10 lutego 2016, https://www.se.pl/wiadomosci/polska/rodzina-kajetana-poznanskiego-rodzice-sadobrze-wyksztalceni-i-majetni-aa-cWsZ-YXD8-GpUc.html [dostęp: 15.12.2018].

32 M. Święchowicz, R. Gębura, Jak bibliotekarz stat się morderca, ,Newsweek” 2016, nr 8, http://www.newsweek.pl/plus/spoleczenstwo/kajetan-poznanski-jak-bibliotekarz-stal-sie-morderca,artykuly,379688,1,z.html [dostęp: 10.10.2017].

33 M. Cedro, B. Figaj, Bibliotekarz morderca obciąt kobiecie głowę piła. Ustalenia prokuratorów o bibliotekarzu Kajetanie P., „Fakt” 2016, nr 30, s. 1, 8.

34 M. Szonert-Binienda, O zamachu na nowo, ,wSieci” 2016, nr 42, s. 69. 
a do tego kompetentna" bibliotekarka z Dęblina zaciągała pożyczki, wykorzystując dane czytelników. To, co jeszcze zasługuje na uwagę, to podpis pod fotografią przestępczyni: „Piękna bibliotekarka wyłudzała kredyty”35.

Media, które opisywały nowy związek znanej aktorki Marii S., w każdą notatkę wplatały informację o tym, że jej partner legitymuje się dyplomem bibliotekarza. Nie ukrywano zdziwienia, że reprezentant tego zawodu może być kimś atrakcyjnym dla przedstawicielki świata filmu! Bez wątpienia dziennikarze tabloidów pozostają pod wpływem stereotypu nudnego, zaniedbanego, ale poczciwego bibliotekarza... „Absolwent bibliotekarstwa ma w środowisku opinię bawidamka, jednak kobiety lgną do niego jak pszczoły do miodu [...]. Czy przez fatalne zauroczenie Maria Seweryn podzieli los byłych partnerek niewiernego bibliotekarza?" — zastanawia się „Fakt”36. Tygodnik „Świat i Ludzie” opisuje sytuację zawodową partnera aktorki bardziej precyzyjnie: „Igor D., z wykształcenia bibliotekarz, prowadzi własną działalność gospodarczą"37. Kolejne pismo dorzuca: „Czy to ten wymarzony? To absolwent bibliotekarstwa i projektant wnętrz, Igor D." 38 Po kilku miesiącach ten temat powraca. Prasa donosi: „Jest coraz ostrzej. [...] Czy będzie w stanie wybaczyć córce? Miłość aktorki do bibliotekarza kwitnie i [ona] na poważnie planuje z nim przyszłość" 39 .

Tabloidy są ukierunkowane na dotarcie do jak najszerszej grupy odbiorców oraz wzbudzenie ich zainteresowania, dlatego potrafią nawet mało istotną informację przedstawić w taki sposób, aby wywołać sensację. Zupełnie inną linię reprezentują tygodniki społeczno-polityczne oraz prasa kobieca. Biblioteki są tam przedstawiane jako instytucje bardzo ważne dla społeczeństwa, a pracujące tam osoby to ludzie pozytywnie wyróżniający się w środowisku, zaradni, z pasją. W ten sposób ujmuje temat „Poradnik Domowy” we wspomnianym artykule Ich praca uśmiech przywraca czy „Dobre Rady”, które przedstawiają sylwetkę dyrektorki biblioteki w Łaziskach:

Do pracy zabrała się z zapałem. Szukała pomysłu, by przyciągnąć ludzi. [...] Zdobyła fundusze na remont i nowe sprzęty do biblioteki, organizowała kolejne imprezy. Ludzie zobaczyli, że jest dziewczyną otwartą na współpracę. [...] Od kiedy Karolina przejęła stery w bibliotece, wiele się zmieniło ${ }^{40}$.

Z kolei „Życie na Gorąco” prezentuje sylwetkę bibliotekarki z Kadzidła, znawczynię gwary i kultury kurpiowskiej, która wkłada mnóstwo energii w populary-

35 Obrzydliwy proceder Beaty P. Robiła to w bibliotece, „Fakt” 2017, http://www.fakt.pl/ wydarzenia/polska/bibliotekarka-z-deblina-zaciagala-kredyty-wykorzystujac-dane-czytelnikow/ x0nkvzy [dostęp: 18.10.2017].

36 B. Pańczyk, Kochanek okłamat córkę Jandy, „Fakt” 2015, nr 1, s. 16.

37 Maria Seweryn. Znów będzie mama!!, „Świat i Ludzie” 2015, nr 10, s. 2.

38 Maria Seweryn. Dzieci sa najważniejsze, ,Rewia” 2015, nr 16, s. 13.

39 Krystyna Janda. Jest coraz ostrzej, „Rewia” 2015, nr 33, s. 3.

40 M. Oszmian, K. Leszczyńska, op. cit., s. 44-47. 
zację miejscowej tradycji, szczególnie kulinarnej ${ }^{41}$. Tenże tygodnik zamieszcza też artykuł o emerytowanej bibliotekarce ze Słupska, która „wypożyczała książki samemu Stanisławowi Lemowi"42, a obecnie realizuje swoje pasje podróżnicze, wrażeniami z nich dzieli się zaś na spotkaniach z czytelnikami, organizowanymi w... bibliotece, w której przepracowała 45 lat! Kobiety z sercem na dtoni — taki tytuł pismo „Dobre Rady” nadaje artykułowi o społeczniczkach, wśród których jedna ,jest emerytowaną bibliotekarką, więc wie, jak zorganizować ciekawe zabawy. I robi to z wielką radością i pasją”. „To dzięki takim kobietom świat staje się lepszy"43.

Nawet, gdy o zawodzie bibliotekarza wspomina się mimochodem, ma on bardzo pozytywne skojarzenia. Wymienia się go bowiem w kontekście losów ludzi wartościowych, zahartowanych w życiowych trudnościach, wiernych ustalonej przez siebie hierarchii wartości. Tygodnik „Na Żywo” wspomina sylwetkę popularnej niegdyś aktorki, która w USA pracowała jako bibliotekarka ${ }^{44}$. Z kolei miesięcznik „Kobieta i Życie” opublikował wspomnienia czytelniczki z trudnych lat dzieciństwa, a w nich wzmiankę o dzielnej i uzdolnionej bibliotekarce ${ }^{45}$. Sylwetkę twórczyni „,biblioteki sąsiedzkiej” na warszawskiej Pradze kreśli „Polityka”46. Inicjatorka tego niezwykłego projektu to urodzony społecznik i działaczka pozarządowa, całkowicie oddana potrzebującym. Przekaz o empatii i uczciwości pracowników biblioteki wzmacnia informacja o niecodziennej sytuacji, która przydarzyła się jednej z ciechanowskich bibliotekarek, podana przez portal tygodnika „Wprost” 47 . Z kolei „Twoje Imperium” przedstawiło czytelnikom małżeństwo emerytowanych bibliotekarzy z Poznania, znanych w swoim mieście także jako wyjątkowi pasjonaci kina ${ }^{48}$. W tę narrację wpisuje się wiersz Leszka Długosza Pochwata bibliotekarek. Krakowski poeta, uczestnik wielu spotkań autorskich, odbywających się głównie w bibliotekach, nie znajduje słów, aby wyrazić swoją wdzięczność i uznanie dla pań, które miał szczęście spotkać w trakcie swoich podróży po kraju:

Na pochwałę Waszą Panie Bibliotekarki...

Panny madonny instytutów

41 K. Grzelska, Fafernuchy pachna miodem i Kurpiami, „Życie na Gorąco” 2014, nr 49, s. $54-55$.

42 Z biblioteki w świat, „Życie na Gorąco” 2012, nr 12, s. 55.

43 S. Monostori, Kobiety z sercem na dtoni, „Dobre Rady” 2017, nr 12, s. 40-41.

44 I. Kraft, Ewa Krzyżewska. Z miłości do ukochanego, „Na Żywo” 2017, nr 34, s. 45.

45 K. Jabłonowska, Zabawka ze starego wykroju, „Kobieta i Życie” 2013, nr 12, s. 108-109.

46 M. Kołodziejczyk, Dobra bibliotekarka w ,złej dzielnicy”, ,Polityka” 2015, https://www. polityka.pl/tygodnikpolityka/spoleczenstwo/1644086,1,dobra-bibliotekarka-w-zlej-dzielnicy.read [dostęp: 15.12.2018].

47 Ciechanów. Bibliotekarka znalazła w Harlequinie 8 tys. złotych, „Wprost” 2018, https:// www.wprost.pl/kraj/10105588/ciechanow-bibliotekarka-znalazla-w-harlequinie-8-tys-zlotych. html [dostęp: 15.12.2018].

48 A. Forecka, Jutro pójdziemy znowu do kina, „Twoje Imperium” 2017, nr 46, s. 16. 
Chorążyny książnic

Skromne szarytki gminnych ośrodków kultury [...]

O jakże wszystkie ja bym was wywyższył [...]

Opiekunkom i Rozdawczyniom Księgi

Cześć i wdzięczność

BIBLIOTEKARKOM POLSKIM - AVE! ${ }^{49}$

Zauważmy, że w wierszu pobrzmiewa potoczne przekonanie o niezamożności bibliotekarek — „skromnych szarytek". Prawdopodobnie intencją autora było podkreślenie heroiczności ich postawy: niedobory finansowe i niedoinwestowanie swoich placówek są w stanie zastąpić gotowością do poświęceń. Dość podobny sposób widzenia prezentuje bibliotekarz z wykształcenia, weteran estrady Leszek Niedzielski, który dyplom absolwenta bibliotekoznawstwa zdobył, studiując ten kierunek na Wydziale Filologicznym Uniwersytetu Wrocławskiego. To właśnie on jest autorem powiedzenia, że „bibliotekarz to nie zawód popłatny, ale poczytny” ${ }^{\circ 0}$. To spore uogólnienie, gdyż

R. Morin z USA musiał uwielbiać swoją pracę w bibliotece University of New Hampshire. Po pierwsze, że przepracował tam pół wieku. Po drugie, że kiedy niedawno zmarł w wieku 77 lat, okazało się, iż cały majątek zapisał uczelni [...], w sumie 4 mln dol., w tym co najmniej 100 tys. dol. musi zostać przeznaczone dla biblioteki ${ }^{51}$.

\section{Podsumowanie i wnioski}

Przegląd źródeł w pewnym, choć niewielkim, stopniu odzwierciedla negatywne, stereotypowe spojrzenie na instytucję biblioteki oraz na zawód i osobę bibliotekarza, jakie zostały zdiagnozowane przez środowisko bibliotekarskie kilkanaście lat temu. Zdecydowanie zanika wizerunek bibliotekarki nieatrakcyjnej wizualnie. Jeśli pojawia się nawiązanie do wyglądu, to raczej zmierza ono ku wykreowaniu innego szablonu — ,piękna i niegodziwa”. Jedynie w serii artykułów o popularnej aktorce i jej życiowym partnerze można się dopatrzyć echa mitu o nieciekawej powierzchowności bibliotekarzy, niezdolnych do wzbudzenia zainteresowania swoją osobą. Podobnie wygląda rzecz w wypadku zatrudnionego w bibliotece mordercy. To oczywiste, że gazety „bulwarowe” są nastawione na sensację i stosują przejaskrawienia. Być może nie będzie nadużyciem, gdy odczytamy dziennikarskie intencje jako kontrapunkt.

A zatem bibliotekarz jest w społeczeństwie postrzegany jako osoba mądra, bezinteresowna, ideowa, chętnie niosąca pomoc innym, będąca uosobieniem spokoju. Stąd szok i niedowierzanie, że także wśród przedstawicieli tego zawodu może znaleźć się ktoś, kto z rozmysłem potrafi skrzywdzić drugiego człowieka. Trzeba

49 L. Długosz, Pochwała bibliotekarek, ,wSieci” 2016, nr 26, s. 3.

50 J. Skoczylas, Elita i Studio 202, Wrocław 2013, s. 110.

51 Ł. Zboralski, Podarek od pracownika, „Do Rzeczy” 2016, nr 37, s. 79. 
docenić także to, że prasa kobieca w artykułach poświęconych ludziom ciekawym, nietuzinkowym znajduje miejsce dla bibliotekarek i w tak pozytywnym świetle pokazuje ich życie i pracę. Taki obraz należy jednak potraktować jedynie jako pewien wycinek opinii publicznej, obecnie bowiem odbiorcami słowa drukowanego, a szczególnie prasy kobiecej i codziennej, stali się głównie ludzie średniego i starszego pokolenia. Zatem nie można mieć pewności, czy tak pozytywnie nakreślony wizerunek bibliotek i bibliotekarzy dociera także do ludzi młodych. To dowodzi, że należy nadal nieprzerwanie prowadzić pracę nad sposobem postrzegania bibliotek i bibliotekarzy, pokazywać ich sukcesy i starania, promować możliwości i podkreślać benefity, jakie daje korzystanie z placówek bibliotecznych.

Widać, że te wysiłki przynoszą efekty. Jednak starania trzeba skierować szczególnie do ludzi młodych i do ich potrzeb dostosować oferty bibliotek, tak kreując wizerunek tych instytucji, aby młodzież uznała, że są to miejsca nowoczesne, interesujące, warte odwiedzania, wiele wnoszące do ich życia. Powinni być przekonani, że bywanie w bibliotece należy do dobrego tonu. Na tym polu jest jeszcze sporo do zrobienia. Choć bowiem w opisywaniu bibliotek, zwłaszcza tych nowo powstających bądź modernizowanych, można dostrzec starania, aby przedstawić czytelnikom nowoczesną stronę tych placówek, ofertę zgodną z osiągnięciami technologii, to nigdzie nie jest to wprost powiązane z pracą bibliotekarzy. Dziennikarze mediów nieskierowanych do ludzi młodych albo tego nie zauważają, albo nie przywiązują do tego wagi. Co więcej, nieustannie trzeba pamiętać, iż to, że dziś są media, które chwalą biblioteki, nie oznacza, że tak będzie zawsze. Wiadomo, że kto nie idzie do przodu, ten się cofa. Zapewne niegdyś bycie ostoją stateczności stanowiło zaletę. Obecnie, kiedy świat ulega tak szybkim przemianom - niekoniecznie. Dziś, aby bibliotekarze i biblioteki utrzymali znaczenie w życiu społecznym, potrzebna jest kreatywność i twórczy dynamizm. Bardzo dobitnie podkreślił to bydgoski dziennikarz: „Innej drogi nie ma. Biblioteki muszą się zmieniać z duchem czasu albo same staną się pomieszczeniami dla duchów"52.

\section{Bibliografia}

Biblioteka na miarę XXI wieku, „Express Bydgoski” 2017, nr 197, s. 23.

Bogucka K., To książkowa metamorfoza!, „Express Bydgoski” 2016, nr 32, s. 7.

Bogumił Kobiela. Przeczuwat, że szybko odejdzie, „Na Żywo” 2017, nr 10, s. 42-43.

Bójka podczas debaty w bibliotece UKW, „Express Bydgoski” 2017, nr 207, s. 2.

Bryson B., Zapiski z małej wyspy, przeł T. Bieroń, Wydawnictwo Zysk i S-ka, Poznań 2009.

Cedro M., Figaj B., Bibliotekarz morderca obciąt kobiecie głowę piła. Ustalenia prokuratorów o bibliotekarzu Kajetanie P., „Fakt” 2016, nr 30, s. 1, 8.

Ciechanów. Bibliotekarka znalazła w Harlequinie 8 tys. złotych, „Wprost” 2018, https://www.wprost. pl/kraj/10105588/ciechanow-bibliotekarka-znalazla-w-harlequinie-8-tys-zlotych.html [dostęp: 15.12.2018].

52 J. Reszka, Tylko ucieczka do przodu, „Express Bydgoski” 2017, nr 197, s. 23. 
Długosz L., Pochwała bibliotekarek, „wSieci” 2016, nr 26, s. 3.

Firlej-Buzon A., Jak wygląda bibliotekarka?, „Poradnik Bibliotekarza” 2003, nr 9, s. 3-6.

Firlej-Buzon A., Jak wyglada bibliotekarka? Cz. 2, „Poradnik Bibliotekarza” 2004, nr 1, s. 8-10.

Forecka A., Jutro pójdziemy znowu do kina, „Twoje Imperium” 2017, nr 46, s. 16.

Golisz E., Ich praca uśmiech przywraca, „Poradnik Domowy” 2014, nr 10, s. 36-38.

Grzelska K., Fafernuchy pachna miodem i Kurpiami, „Życie na Gorąco” 2014, nr 49, s. 54-55.

http://demotywatory.pl/4493808/Na-zapleczu-miejskiej-biblioteki-policja-odkryla-hodowlemarihuany [dostęp: 3.10.2017].

Jabłonowska K., Zabawka ze starego wykroju, „Kobieta i Życie” 2013, nr 12, s. 108-109.

Jakubowski J., Jakznika Polska powiatowa, „Nowości. Dziennik Toruński” 2012, nr 108, http://www. nowosci.com.pl/archiwum/a/jak-znika-polska-powiatowa,10923891/ [dostęp: 26.04.2012].

Kołodziejczyk M., Dobra bibliotekarka w ,złej dzielnicy”, „Polityka” 2015, https://www.polityka. pl/tygodnikpolityka/spoleczenstwo/1644086,1,dobra-bibliotekarka-w-zlej-dzielnicy.read [dostęp: 26.12.2018].

Kowalska B., Kotlarek D., Bibliotekarz a stereotypy, „EBIB” 2006, nr 10, http://www.ebib.pl/2006/ 80/a.php?kowalska_kotlarek [dostęp: 19.09.2017].

Kraft I., Ewa Krzyżewska. Z miłości do ukochanego, „Na Żywo” 2017, nr 34, s. 45.

Krystyna Janda. Jest coraz ostrzej, „Rewia” 2015, nr 33, s. 3.

Kształtowanie wizerunku biblioteki, red. M. Czyżewska, Wydawnictwo Wyższej Szkoły Ekonomicznej w Białymstoku, Białystok 2007.

Marcinkowski P., Bibliotekarz. Stereotyp czy wizerunek?, http://eprints.rclis.org/7083/1/stereotyp. pdf [dostęp: 19.09.2017].

Maria Seweryn. Dzieci sa najważniejsze, „Rewia” 2015, nr 16, s. 13.

Maria Seweryn. Znów będzie mama!', „Świat i Ludzie” 2015, nr 10, s. 2.

Monostori S., Kobiety z sercem na dłoni, „Dobre Rady” 2017, nr 12, s. 40-41.

Narbutt M., Mroczne pasje bibliotekarza, „wSieci” 2016, nr 7, s. 41.

Nesser H., Kobieta ze znamieniem, przeł. M. Kłos, Wydawnictwo Czarna Owca, Warszawa 2013.

Nesser H., Nieszczelna sieć, przeł. W. Łygaś, Wydawnictwo Czarna Owca, Warszawa 2012.

Obrzydliwy proceder Beaty P. Robiła to w bibliotece, „Fakt” 2017, http://www.fakt.pl/wydarzenia/ polska/bibliotekarka-z-deblina-zaciagala-kredyty-wykorzystujac-dane-czytelnikow/x0nkvzy [dostęp: 18.10.2017].

Oszmian M., Leszczyńska K., Jak dobrze wrócić w rodzinne strony!, „Dobre Rady” 2015, nr 9, s. $44-47$.

Pańczyk B., Kochanek oktamat córkę Jandy, „Fakt” 2015, nr 1, s. 16.

Pavlović I., Dla taty byłam księżniczka, „Na Żywo” 2011, nr 39, s. 18-19.

Pavlović I., Mą̇ zdobyt mnie podstępem, „Super Express” 2011, http://www.se.pl/wiadomosci/ gwiazdy/iwona-pavlovic-maz-zdoby-mnie-podstepem_207112.html [dostęp: 4.10.2017].

Przybylska J., Bibliotekarze w opinii czytelników, „Bibliotekarz” 1995, nr 11, s. 18-22.

Reszka J., Tylko ucieczka do przodu, „Express Bydgoski” 2017, nr 197, s. 23.

Rodzina Kajetana Poznańskiego. Rodzice sa dobrze wykształceni i majętni, „Super Express” 2016, https://www.se.pl/wiadomosci/polska/rodzina-kajetana-poznanskiego-rodzice-sa-dobrzewyksztalceni-i-majetni-aa-cWsZ-YXD8-GpUc.html [dostęp: 15.12.2018].

Roszkowska D., Wizerunek bibliotekarza. Zestawienie bibliograficzne w wyborze, http://www.pedagogiczna.edu.pl/zest409.htm [dostęp: 30.06.2017].

Sawicka D., Obalić mity, „EBIB” 2004, nr 5, http://www.ebib.pl/2004/56/sawicka.php [dostęp: 27.10.2017].

Skoczylas J., Elita i Studio 202, Wydawnictwo Dolnośląskie, Wrocław 2013.

Szczepańska B., Cicha przystań?, „EBIB” 1999, nr 1, http//www.oss.wroc.pl/biuletyn/ebib01/cicha_przystan.html [dostęp: 26.09.2017].

Szonert-Binienda M., O zamachu na nowo, „wSieci” 2016, nr 42, s. 69. 
„Sztuka przetrwania” w bibliotece miejskiej w Grudziądzu, „Gazeta Pomorska” 2017, nr 160, http:// www.pomorska.pl/wiadomosci/grudziadz/a/sztuka-przetrwania-w-bibliotece-miejskiej-wgrudziadzu,12263573/ [dostęp: 12.07.2017].

Święchowicz M., Gębura R., Jak bibliotekarz stat się morderca, „Newsweek” 2016, nr 8, http:// www.newsweek.pl/plus/spoleczenstwo/kajetan-poznanski-jak-bibliotekarz-stal-sie-morderca,artykuly,379688,1,z.html [dostęp: 10.10.2017].

Wojciechowski J., W imadle stereotypów, „Bibliotekarz” 2004, nr 2, s. 3-6.

Z biblioteki w świat, „Życie na Gorąco” 2012, nr 12, s. 55.

Zalewski I., Pean na cześć bibliotek, „Do Rzeczy” 2014, nr 1, s. 63.

Zboralski Ł., Podarek od pracownika, „Do Rzeczy” 2016, nr 37, s. 79.

Zygmunt M., Wizerunek bibliotekarki - czy się zmienia?, [w:] Ksztaltowanie wizerunku biblioteki, red. M. Czyżewska, Wydawnictwo Wyższej Szkoły Ekonomicznej w Białymstoku, Białystok 2007, s. 13-22.

\section{More about the image of a library and a librarian from the perspective of popular media}

Summary

Libraries and librarians have undergone tremendous changes in recent years. This undeniable fact led the representatives of the librarian community to reflect on the social reception of this change. The article presents a summary of discussions from previous years, and these conclusions are confronted with the current perception of libraries as well as the librarian profession. The current image of the field mentioned above was prepared based on materials published in popular media. An attempt was made to answer the question of whether the true image of the librarian, educated and fluent in modern information technology, went hand in hand with their social perception.

KEYWORDS: stereotype of librarian, image of library 